\title{
Genetic Algorithm Based Nesting Method with Considering Schedule for Sheet Metal Processing*
}

\author{
Tatsuhiko SAKaguchi ${ }^{\dagger}$, Hayato OHTANi ${ }^{\dagger}$ and Yoshiaki Shimizu ${ }^{\dagger}$
}

\begin{abstract}
In recent years, efficient and agile manufacturing is aimed at in many manufacturing industries. In sheet metal processing, reducing the waste of raw materials and managing the suitable production schedule are the important factors for such manufacturing. Nesting is executed to determine the optimal layout for raw material. And scheduling is executed to determine the suitable schedule. Generally, nesting and scheduling are executed separately because their optimization objectives are different. However there occurs a certain trade-off between nesting and scheduling. Therefore, those problems should be considered simultaneously in order to increase the efficiency of entire manufacturing activity. Under such understanding, in this study, we propose an nesting method with considering schedule. In this method, we apply Genetic Algorithm to solve the nesting problem. We propose a new fitness function which considers both reduction of waste material and minimizing total tardiness. Finally, we verify the effectiveness of the proposed method through some computational experiments.
\end{abstract}

\section{Introduction}

In recent years, manufacturing industries face with the rising raw material costs and the diversified customers' needs. Moreover, manufacturing lead-time is becoming shorter and shorter. In order to provide various products in shorter lead-time and at low price, therefore, efficient and agile manufacturing is aimed at in many manufacturing industries. Reducing the waste of raw materials and managing the suitable production schedule are the important factors for such efficient and agile manufacturing.

In sheet metal processing, 3D shape of all parts of products are developed into $2 \mathrm{D}$ surface. Then the parts are assigned to the sheet metal. This decision of layout is called nesting. After nesting, each part is cut off from sheet metals in punching process. After cutting the parts, the manufacturing sequence for the following manufacturing process is decided through scheduling. Typically, the objective of nesting is to minimize the waste of raw materials, and that of scheduling is to minimize the make-span or total tardiness. Thus, the nesting and the scheduling have different objectives essentially, so they have been considered separately in each management sector. However, they are affected with each other and there is trade-off between the respective objectives.

\footnotetext{
* Manuscript Received Date: August 8, 2014

$\dagger$ Department of Mechanical Engineering, Toyohashi University of Technology; 1-1, Hibarigaoka, Tenpaku-cho, Toyohashi city, Aichi 441-8580, JAPAN

Key Words: nesting, scheduling, genetic algorithm, sheet metal processing.
}

Therefore, those problems should be considered simultaneously in order to increase the efficiency of entire manufacturing activity.

In our previous study, we have proposed an integrated method of scheduling and nesting[1]. This study decides the suitable schedule by using dispatching rule firstly. Then according to the starting time of each part decided by scheduling, the cutting layout is determined. By this procedure, the suitable layout with considering schedule can be obtained. However, generally, the cutting layout has to be determined before scheduling, because the punching process cannot start without deciding the cutting layout. Therefore, in the actual manufacturing systems, nesting which determine the cutting layout is done before scheduling. In such a case, in order to obtain both suitable layout and suitable schedule, it is necessary to consider the schedule at the stage of nesting.

Under such understanding, in this study, we propose an Genetic Algorithm based nesting method with considering schedule. In this method, we apply a new fitness function which considers both reduction of waste material and minimizing total tardiness. Finally, we verify the effectiveness of the proposed method through some computational experiments.

\section{Problem Description}

\subsection{Nesting Problem}

In sheet metal processing, parts are cut from a rectangular sheet metal by using a turret punch press or a laser beam machine. In order to reduce a waste material, parts are arranged in a sheet metal as many 
as possible. This arranging operation is called nesting. Nesting is a spatial layout problem which decide where a part is located without overlapping with already-located parts within a rectangular sheet metal. Fig. 1 shows an example of nesting result. Generally, the shape of parts is irregular, and the thickness typically varies between 1 and $10 \mathrm{~mm}$. For simplicity, in this study, we assume the following conditions.

(1) The shape of parts and sheet metals is filled rectangle.

(2) Thickness of parts and sheet metal is constant.

Under the above conditions, we can solve the nesting problem as a two dimensional bin packing problem $[2-5]$. We formulate the nesting problem as follows.

$$
\text { Minimize } \sum_{k \in K} \delta_{k}
$$

Subject to

$$
\begin{aligned}
& \sum_{k \in K} \gamma_{i, k}=1, \quad \forall i \in I \\
& \sum_{i \in I} l_{i} w_{i} \gamma_{i, k} \leq L W \delta_{k}, \quad \forall k \in K \\
& 0 \leq x_{i} \leq W-w_{i}, \quad \forall i \in I \\
& 0 \leq y_{i} \leq L-l_{i}, \quad \forall i \in I
\end{aligned}
$$

At least one of the next four inequalities holds for every pair $i$ and $i^{\prime}$.

$$
\begin{aligned}
& \left(x_{i}+w_{i}\right) \gamma_{i, k} \leq x_{i^{\prime}} \gamma_{i^{\prime}, k}, \quad \forall k \in K \\
& \left(x_{i^{\prime}}+w_{i^{\prime}}\right) \gamma_{i^{\prime}, k} \leq x_{i} \gamma_{i, k}, \quad \forall k \in K \\
& \left(y_{i}+l_{i}\right) \gamma_{i, k} \leq y_{i^{\prime}} \gamma_{i^{\prime}, k}, \quad \forall k \in K \\
& \left(y_{i^{\prime}}+l_{i^{\prime}}\right) \gamma_{i^{\prime}, k} \leq y_{i} \gamma_{i, k}, \quad \forall k \in K
\end{aligned}
$$

where,

$k$ : Sheet number $(k=1 \cdots K)$

$\delta_{k}: 0-1$ variable. If $k^{\text {th }}$ sheet is used, set $\delta_{k}=1$. Otherwise, 0 .

$\gamma_{i, k}: 0-1$ variable. If part $i$ is arranged to $k^{\text {th }}$ sheet, set $\gamma_{i, k}=1$. Otherwise, 0 .

$l_{i}$ : Length of part $i$

$w_{i}$ : Width of part $i$

$L$ : Length of sheet

$W$ : Width of sheet

$x_{i}: x$-coordinate of bottom left corner of part $i$

$y_{i}: y$-coordinate of bottom left corner of part $i$

Eq. (1) represents the objective function that tries to minimize the number of sheet metals. Eq. (2) means that all parts should be arranged to either sheet metal. Eqs. (3) to (5) means that all parts must be place into the sheet metal. Eqs. (6) to (9) means that no two parts overlap.

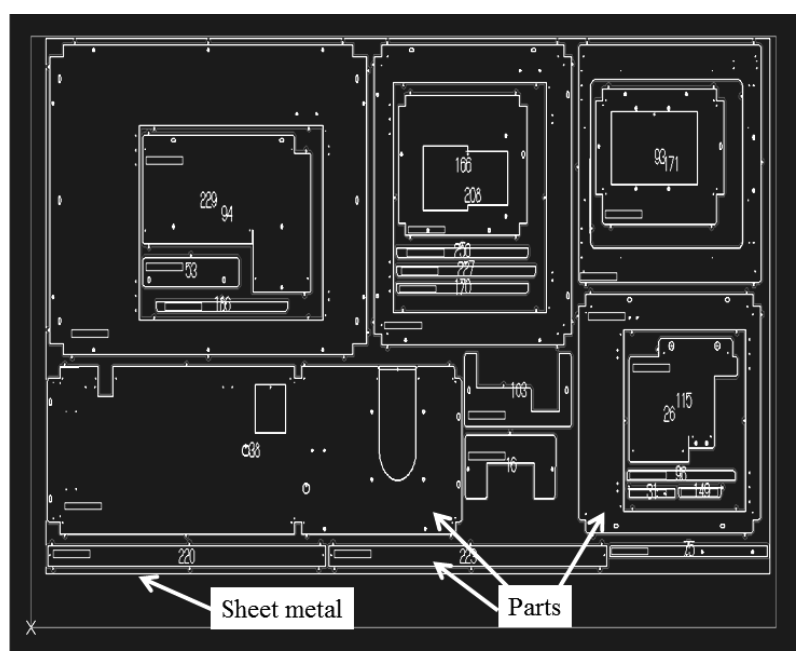

Fig. 1 Example of nesting result

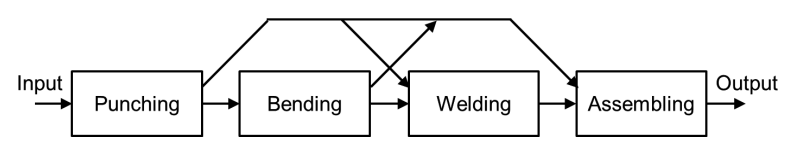

Fig. 2 Process sequence of sheet metal processing

\subsection{Scheduling Problem}

The scheduling type of the sheet metal processing is basically a flow shop. The processes are composed of punching, bending, welding and assembling. All parts are processed in each process in the same order, though some parts can skip some of the following processes as shown in Fig. 2. This causes unbalance of workload. In this study, we solve the total tardiness minimization problem under the following conditions.

(1) Product $m(m=1 \cdots M)$ is consisted of one or more parts.

(2) Every product has a different due date $D D_{m}$.

(3) Every part is processed at one or more processes.

(4) Required process for each part is predetermined.

(5) Processing time of part $i$ in product $m$ at process $n(n=1 \cdots N)$ is $p t_{i, m, n}$.

(6) Two or more parts cannot be processed simultaneously at bending process.

(7) Multiple parts are processed simultaneously at punching, welding and assembling process.

In addition, we define maximum float of part $i$ in product $m$ by the following equation, in order to evaluate how much time a part has by its due date. It is better that a part which has early due date and long processing time is processed as early as possible.

$$
M F_{i, m}=D D_{m}-\sum_{n \in N} p t_{i, m, n}
$$

where,

$M F_{i, m}$ : Maximum float of part $i$ of product $m$ $D D_{m}$ : Due date of product $m$ 
: Parts of same product whose due date is today : Parts of same product whose due date is next week Sheet metal Parts

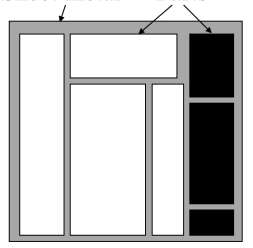

$\underline{1^{\text {st }} \text { sheet, }}$ Processing date: Today

(a) Optimal layout (Minimizing waste of raw material)

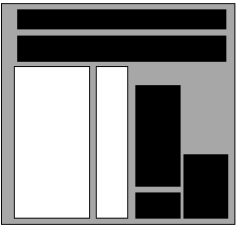

$1^{\text {st }}$ sheet, Processing date: Today

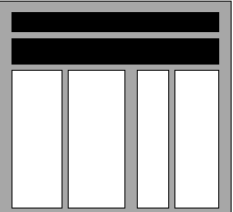

$2^{\text {nd }}$ sheet, Processing date: Tomorrow

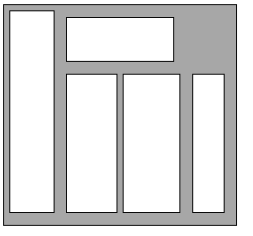

$\underline{2^{\text {nd }} \text { sheet, }}$ Processing date: Tomorrow

$\underline{3}^{\text {rd }}$ sheet,

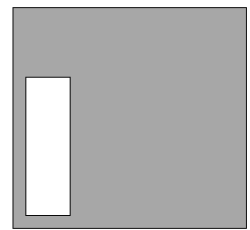

Processing date: Day after tomorrow

(b) Another layout (Satisfying due date)

Fig. 3 Relation between nesting and scheduling

$p t_{i, m, n}$ : Processing time of part $i$ of product $m$ at process $n$

\subsection{Relation between Nesting and Scheduling}

Fig. 3 shows two cases of nesting result under the same condition. Large gray rectangles represent sheet metal. And small rectangles within the sheet metal represent parts to be produced. Same color parts represent the parts of same product. In Fig. 3(a), the layout is determined in order to minimize the waste of material. This case uses 2 sheet metal to cut all 13 parts. On the other hand, in Fig. 3(b), the layout is determined in order to satisfy due date. This case needs 3 sheet metal. Therefore, the waste of material increases in this case. However, in case (a), black parts are assigned in each sheet metal separately. If due date of the product which is consisted of these black parts is set to today, and the processing date of second sheet metal is scheduled to tomorrow, this product cannot satisfy due date. Like this situation, the relation between nesting and scheduling is considered a trade-off. There exists many researches dealing with nesting and scheduling problems. However, almost all of studies have solved those separately. Chryssolouris et al. [6] proposed a rule base decisionmaking approach for combined problem of scheduling and nesting. This paper intends to a textile industry, hence only a cutting process is considered in scheduling.

\section{Integration of Nesting and Schedul- ing}

\subsection{Entire Procedure of Nesting and Scheduling}

In order to implement nesting system associated with scheduling, we propose an integrated method of nesting and scheduling. Below, we describe the procedures of our method.

Step1: GA based nesting

Create layout patterns by using genetic algorithm. Step2: Dispatching rule based scheduling

Determine the schedule by using EDD (Earliest Due Date) dispatching rule for each layout.

Step3: Final solution

Obtain final solution according to the following decision variable.

$$
\begin{aligned}
D V_{j}=\frac{N O F_{j}-\min _{j \in J}\left[N O F_{j}\right]}{\max _{j \in J}\left[N O F_{j}\right]-\min _{j \in J}\left[N O F_{j}\right]} \\
+\frac{S O F_{j}-\min _{j \in J}\left[S O F_{j}\right]}{\max _{j \in J}\left[S O F_{j}\right]-\min _{j \in J}\left[S O F_{j}\right]}
\end{aligned}
$$

where,

$N O F_{j}$ : Objective function value of nesting for layout pattern $j$

$S O F_{j}$ : Objective function value of scheduling for layout pattern $j$

\subsection{GA Based Nesting}

We apply Genetic Algorithm to solve the nesting problem. Below, we describe the procedures of GA based nesting method.

\section{Step1: Creation of initial individuals}

Create $p$ special individuals and $P-p$ randomlycreated individuals for initial population. ( $P$ : Population size)

Step2: Calculation of fitness value

Calculate the fitness value according to the number of sheet metal and maximum float.

Step3: Creation of individuals in the next generation

Repeat the following genetic operations until the number of individuals in the next generation reaches population size.

Step3-1: Selection

Roulette strategy together with elite preservation policy.

Step3-2: Crossover

Select parents individuals randomly, and perform multi-point crossover according to crossover rate.

Step3-3: Mutation

Perform mutation according to mutation rate. Step4: Termination

If the number of generation reaches predetermined number, terminate. Otherwise, repeat from Step2.

In this study, the sequence of chromosome represents the parts assignment priority. Hence the gene al- 


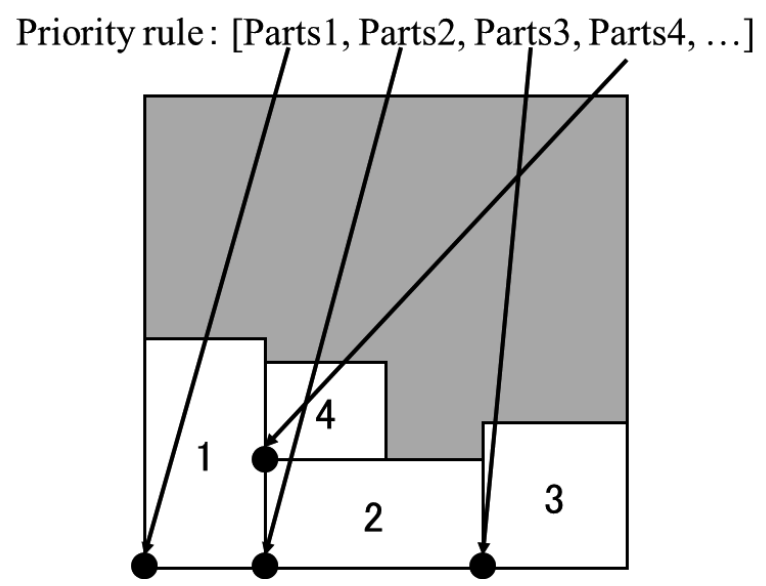

Fig. 4 Bottom left algorithm

located to the left side is assigned to sheet metal more early. In order to decide the position where each part is assigned, we apply Bottom Left algorithm[7,8]. In $\mathrm{BL}$ algorithm, the part is placed into its lowest possible location, and left-justifying it, in accordance with the predetermined assignment priority, as shown in Fig. 4. In genetic operation, we applied PMX[9] and Inverse as crossover and mutation, respectively.

\subsection{Special Individuals}

To enhance the searching ability of GA, we have introduced some special initial individuals at Step1 of GA based nesting. If the individuals with high fitness (elite) are included in the initial population, it is known that solution becomes more accurate and convergence becomes faster[10]. Hence, we introduce two kinds of special individuals. For the first one, the sequence of chromosome is determined according to the size of each part. As mentioned already, we apply BL algorithm to decide the assignment position of parts. It is known that the better solution can be obtained when the parts are arranged in descending order of its size. On the other hand, the second one is generated according to maximum float. We try to minimize not only the number of sheet metal but also total tardiness in nesting. Hence the parts which have an earlier due date should be assigned to the sheet metal which is processed early. Thus we calculate maximum float calculated by eq. (10), then sort the parts in accordance with the ascending order of maximum float.

We also create semi-special individuals by exchanging genes' position partially. The rest of the individuals are created randomly.

\subsection{Fitness Function}

In order to consider both objectives of nesting and scheduling, we propose a fitness function which combines the number of sheet metal and the maximum float. Fitness value $f$ is calculate by the following equation.

$$
f=w_{1} f_{\text {sheet }}+w_{2} f_{\text {float }}
$$

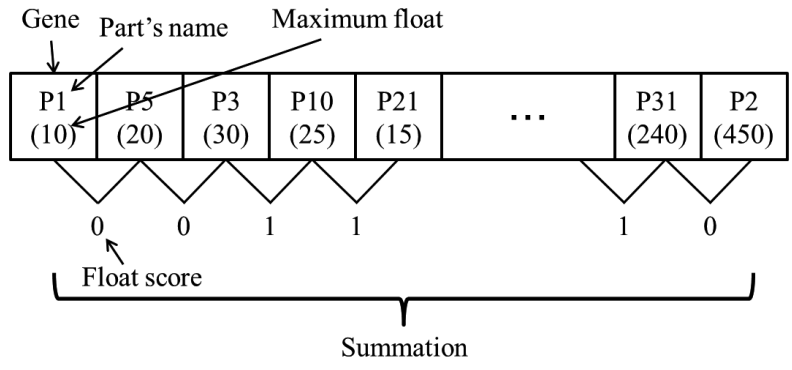

Fig. 5 Fitness calculation based on maximum float

$$
\begin{aligned}
& w_{1}+w_{2}=1 \\
& f_{\text {sheet }}=\frac{f_{s, g}-\min _{g \in G}\left[f_{s, g}\right]}{\max _{g \in G}\left[f_{s, g}\right]-\min _{g \in G}\left[f_{s, g}\right]} \\
& f_{\text {float }}=\frac{f_{f, g}-\min _{g \in G}\left[f_{f, g}\right]}{\max _{g \in G}\left[f_{f, g}\right]-\min _{g \in G}\left[f_{f, g}\right]}
\end{aligned}
$$

where,

$f_{\text {sheet }}$ : normalized fitness value for evaluating the number of sheet metal

$f_{\text {float }}$ : normalized fitness value for evaluating maximum float

$w_{1}, w_{2}$ : weight factors

$f_{s, g}$ : fitness value of individual $g(g=1 \cdots G)$ for evaluating the number of sheet metal

$f_{f, g}$ : fitness value of individual $g$ for evaluating maximum float

$f_{s, g}$ represents the fitness value for evaluating the number of sheet metal and it is equal to the number of sheet metal. As mentioned before, the number of sheet metal can be obtained by applying BL algorithm. $f_{f, g}$ represents the fitness value for evaluating maximum float. Fig. 5 shows the calculation method of $f_{f, g}$. In this figure, each box shows the gene that represents the part. Number in parenthesis represents the maximum float which is calculated by eq. (10). As mentioned already, since the gene allocated to the left side is assigned to the sheet metal more early, it is better that the parts which has early due date are located at the left side. Therefore, the maximum float of neighboring gene is compared. Then if the maximum float of left gene is smaller than that of right gene, float score is set to 0. Otherwise, 1. After that, $f_{f, g}$ is calculated as summation of this float score.

\section{Numerical Experiments}

\subsection{Validation for Effectiveness of Pro- posed Method}

In order to verify the effectiveness of the proposed method, we carried out 10 different case studies whose computational conditions are shown in Table 1 . Thereat, case $1-1,1-2$ and $2-1,2-2$ and $3-1,3-2$ and $4-1,4-$ 2 and 5-1, 5-2 are respectively subject to the same conditions except for the number of products.

The main purpose of this experiment is to validate the effectiveness of proposed fitness function which considers both nesting and scheduling objectives. 
Table 1 Experiment conditions

\begin{tabular}{|c|c|c|c|c|}
\hline $\begin{array}{l}\text { Case } \\
\text { num. }\end{array}$ & $\begin{array}{l}\text { Num. } \\
\text { of } \\
\text { product }\end{array}$ & $\begin{array}{c}\text { Num. } \\
\text { of } \\
\text { part }\end{array}$ & $\begin{array}{l}\text { Parts } \\
\text { size } \\
(x, y)\end{array}$ & $\begin{array}{c}\text { Material } \\
\text { size } \\
(X, Y)\end{array}$ \\
\hline $1-1$ & 5 & & \multirow{10}{*}{$\begin{array}{c}{[1,10]} \\
\mathrm{x}[1,10]\end{array}$} & \multirow{2}{*}{$15 \times 15$} \\
\hline $1-2$ & 10 & 20 & & \\
\hline $2-1$ & 5 & \multirow{2}{*}{32} & & \multirow{2}{*}{$10 \times 20$} \\
\hline $2-2$ & 10 & & & \\
\hline $3-1$ & 5 & \multirow{2}{*}{36} & & \multirow{2}{*}{$20 \times 10$} \\
\hline $3-2$ & 10 & & & \\
\hline $4-1$ & 5 & \multirow{2}{*}{31} & & \multirow{2}{*}{$20 \times 20$} \\
\hline $4-2$ & 10 & & & \\
\hline $5-1$ & 5 & \multirow{2}{*}{26} & & \multirow{2}{*}{$15 \times 20$} \\
\hline $5-2$ & 10 & & & \\
\hline
\end{tabular}

In our study, we do not consider the rotation of part. Therefore, we prepared two types of rectangle. One is the vertically long rectangle. Another is the horizontally long rectangle. The number of vertically long rectangles and horizontally long rectangles is set as a ratio of 4 to 6 .

The characteristic of nesting condition for each case is summarised in Table 2. In this table, parts size represents that the area of parts is small or large compared to the area of sheet metal. Variation in parts size represents that the standard deviation of area of part is small or large.

As a scheduling condition, we set the number of machines at each process as follows. Job assignment for each machine has been predetermined by process planning. However, only the bending process has alternative machine. Hence we chose a machine that can process in a shortest processing time when applying the dispatching rule.

- Puncing : 1

- Bending : 3

- Welding : 3

- Assembling : 2

Every product has 1 to 5 parts for all cases. A product which has only one part does not need a welding and assembling process. On the other hand, a product which has more than one part should be processed at a welding or assembling process. At a welding and assembling process, a part should wait until all combined parts arrive. This causes a bottleneck of schedule. We set due date of product to 1 to 15 times of total processing time of each product. The number of operations is about 200 for case (1 5)-1, 400 for case (1 5)-2, respectively. We set the processing time between 1 to 100 randomly for each part at each process.

The characteristic of scheduling condition for each case is summarised in Table 3 . In this table, skip rate represents the ratio of the number of parts which skips each process to total number of parts.

We set GA parameters as follows according to the preliminary experiments.
Table 2 Characteristic of nesting condition

\begin{tabular}{|c|c|c|c|c|}
\hline Case & $\begin{array}{c}\text { Material } \\
\text { size }\end{array}$ & $\begin{array}{c}\text { Material } \\
\text { shape }\end{array}$ & $\begin{array}{c}\text { Parts } \\
\text { size }\end{array}$ & $\begin{array}{c}\text { Variation in } \\
\text { parts size }\end{array}$ \\
\hline 1 & Middle & Square & Large & Small \\
\hline 2 & Small & $\begin{array}{c}\text { Width }> \\
\text { Height }\end{array}$ & Large & Large \\
\hline 3 & Small & $\begin{array}{c}\text { Width }< \\
\text { Height }\end{array}$ & Large & Large \\
\hline 4 & Large & Square & Small & Large \\
\hline 5 & Middle & $\begin{array}{c}\text { Width }> \\
\text { Height }\end{array}$ & Small & Large \\
\hline
\end{tabular}

Table 3 Characteristic of nesting condition

\begin{tabular}{|c|c|c|c|c|}
\hline & $\begin{array}{c}\text { Skip } \\
\text { rate } \\
\text { (Bend.) }\end{array}$ & $\begin{array}{c}\text { Skip } \\
\text { rate } \\
\text { (Weld.) }\end{array}$ & $\begin{array}{c}\text { Skip } \\
\text { rate } \\
\text { (Assy.) }\end{array}$ & $\begin{array}{c}\text { Due } \\
\text { date }\end{array}$ \\
\hline 1 & $\underline{27 \%}$ & $54 \%$ & $35 \%$ & loose \\
\hline 2 & $\underline{\mathbf{1 9 \%}}$ & $41 \%$ & $\underline{\mathbf{2 5 \%}}$ & loose \\
\hline 3 & $47 \%$ & $44 \%$ & $33 \%$ & tight \\
\hline 4 & $\underline{29 \%}$ & $48 \%$ & $\underline{19 \%}$ & tight \\
\hline 5 & $\underline{\mathbf{1 9 \%}}$ & $38 \%$ & $\underline{\mathbf{1 9 \%}}$ & loose \\
\hline
\end{tabular}

- Population size : 30

- Generation size : 300

- Crossover rate : 0.8

- Mutation rate : 0.1

- Number of special individual based on parts size : 1

- Number of special individual based on maximum float : 1

- weight for nesting $w_{1}$, for scheduling $w_{2}: 0.5$, 0.5

We compared the result of proposed method to those of conventional methods.

There are two conventional methods.

In conventional method 1 , we set the weight factor $w_{1}$ in eq. (12) as 1 . This means that we only considered the number of sheet metal for the fitness function. And also, we include one special individual that is created based on parts size.

Conventional method 2 is our previous proposed method[1]. In conventional method 2, dispatching rule scheduling is executed before nesting. After scheduling, nesting is executed by applying BL algorithm whose assignment priority is sorted according to the starting time of operations.

We can said that conventional method 1 aims at the minimization of the number of sheet metal, and conventional method 2 aims at the minimization of total tardiness.

On the other hand, the proposed method considers both the number of sheet metal and total tardiness. Therefore, for minimizing the number of sheet metal, it is expected that conventional method 2 is the best, the proposed method is the second, and conventional method 1 is the worst effective method. For minimizing total tardiness, it is expected that conventional method 1 is the best, the proposed method is the sec- 
ond, and conventional method 2 is the worst effective method.

We carried out 10 trials for each case. Fig. 6 shows the results (averaged value) of comparison between proposed method and conventional methods.

For nesting, the number of sheet metal obtained by the proposed method is smaller than that of conventional method 2 in all cases. The results of conventional method 1 is better than those of proposed method. However the difference between these methods is less than 1 sheet except for case $4-2$. In case $4-2$, the size of sheet metal is large. On the other hand, the size of part is small and the standard deviation of area of part is large as shown in Table 2 . Under this condition, various allocation patterns exist compared to other cases. Therefore, the difference became larger than other cases. However, it is just 1.6.

For scheduling, we were able to obtain a shorter total tardiness by the proposed method in 6 cases (white bars in Fig. 6) compared to that of conventional method 1 . In case 1 and 4 , the skip rate at bending process and welding process is relatively large. This means that the number of parts which skips bending and welding process is large. In bending process, parts cannot be processed simultaneously. On the other hand, in welding process, they are processed simultaneously. In our proposed method, we use maximum float as one of fitness function of GA. Therefore, the operations which have a longer total tardiness and have a earlier due date are given high priority. We think this is effective for a case that the skip rate is relatively higher. Moreover, in case 1 and 4, the total tardiness obtained by conventional method 2 is longest (light gray bars in Fig. 6). In conventional method 2, scheduling is executed before nesting by applying EDD dispatching rule. The scheduling type of sheet metal processing is a flow-shop and the first process is bending process. Therefore, the starting time of each operation is determined from bending process based on its due date. This method considers only due date and due date is set based on the total processing time of parts, the parts which skip welding process tend to have priority at bending process. Thus total tardiness became long in these cases. On the other hand, in case 2 and 5 those skip rate is small, we were not able to obtain a good result by the proposed method (light gray bar in Fig. 6). In these cases, most parts should be processed at bending and assembling process as shown in Table 3, so the difference of maximum float of each part became small. Fitness function based on maximum float did not work well in these cases. Thus total tardiness became large.

\subsection{Validation for Effectiveness of Spe- cial Individuals}

In order to verify the effectiveness of special individuals, we carried out some additional experiments.

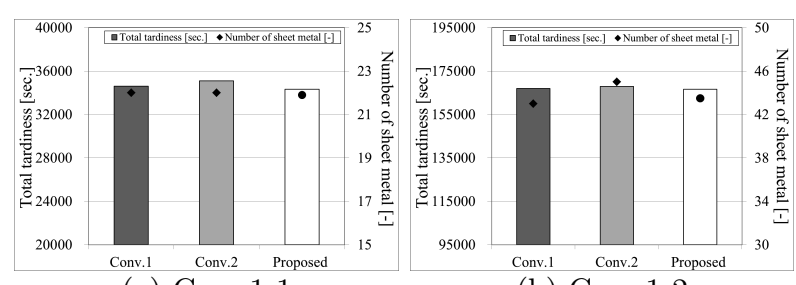

(a) Case 1-1

(b) Case 1-2

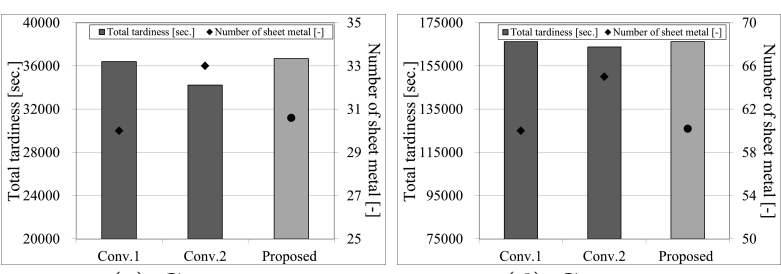

(c) Case 2-1

(d) Case 2-2

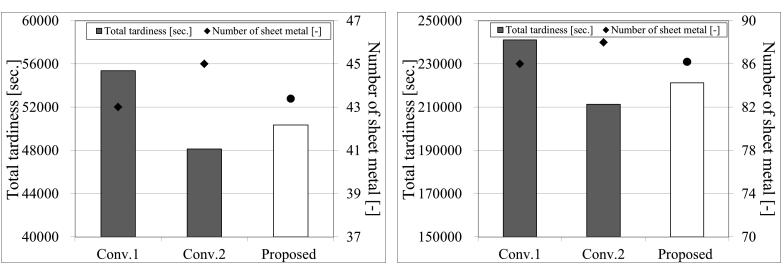

(e) Case 3-1

(f) Case 3-2

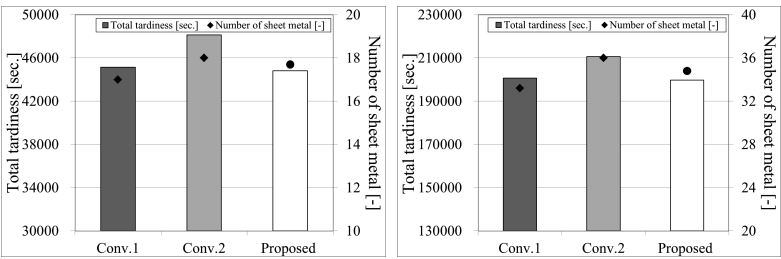

(g) Case 4-1

(h) Case 4-2

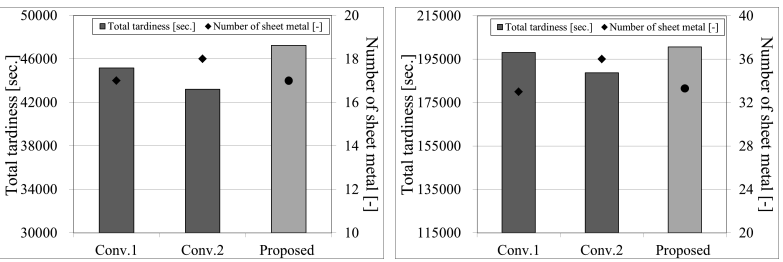

(i) Case 5-1

(j) Case 5-2

Fig. 6 Comparison between proposed method and conventional methods

We created 5 cases whose conditions of initial population are different. Their conditions are as follows.

(A) All individuals in the initial population are created randomly. : "Random"

(B) One special individual which is created based on parts size is included. And other individuals are created randomly. : "Special (Parts size)"

(C) One special individual which is created based on maximum float is included. And other individuals are created randomly. : "Special (Max. float)"

(D) Two special individuals which are created based on parts size and maximum float respectively are included. And other individuals are created randomly. : "Special (Both)" 
(E) Two special individuals which are created based on parts size and maximum float respectively are included. And semi-special individuals are also included. Other individuals are created randomly. : Special + Semi"

We applied these conditions to case $3-1$ in the previous section, and carried out 10 trials of computational experiments for each condition. We set the parameters of GA as follows.

- Population size : 30

- Generation size : 100

- Crossover rate : 0.8

- Mutation rate : 0.1

- Number of special individual based on parts size : 1 (Case B, D and E)

- Number of special individual based on maximum float : 1 (Case C, D and E)

- Number of semi-special individual based on parts size : 4 (Case E)

- Number of semi-special individual based on maximum float : 4 (Case E)

- weight for nesting $w_{1}$, for scheduling $w_{2}$ : 0.5 , 0.5

Fig. 7 shows the results of experiments. We compared the results of total tardiness and the number of sheet metal under the five conditions. The number of sheet metal in the best result is 43 (Special (Max. float)), and that in the worst result is 44(Special (Parts size)). The reduction rate which is calculated by ( 1 - min. / max.) is about $2.3 \%$. This means that we were able to obtain almost optimum solutions for nesting in all cases. On the other hand, total tardiness in the best result is 46977 (Special (Max. float)), and that in the worst result is 56526.3 (Special (Parts size)). The reduction rate is about $16.9 \%$. From these results, a special individual that suits for respective problem is effective for minimizing respective objectives. Especially a special individual based on maximum float is very effective for minimizing total tardiness.

On the other hand, by including both of special individuals, we were able to obtain shorter total tardiness without increasing the number of sheet metal so much. Moreover, by including semi-special individuals, we were able to obtain more shorter total tardiness. Semi-special individuals are created by exchanging gene's position of special individual partially. This procedure is similar to mutation of genetic operation. Therefore, by including semi-special individuals, the divergence of initial individuals is grown and we can avoid local minimum. As a result, we were able to obtain shorter total tardiness in "Special + Semi" compared to "Special (Both)".

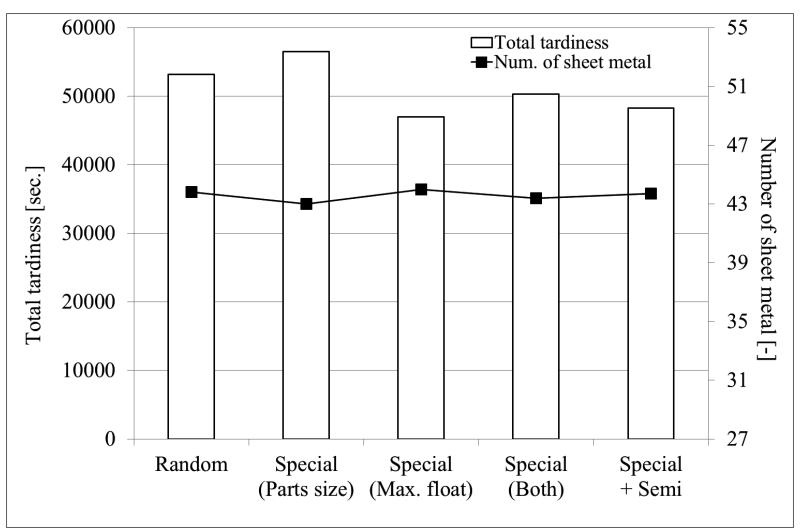

Fig. 7 Validation of special individuals

\section{Conclusion}

This paper has proposed an Genetic Algorithm based nesting method with considering schedule. In this method, we apply the Genetic Algorithm to solve the nesting problem. To consider both nesting and scheduling, we propose a fitness function for evaluating the number of sheet metal and the maximum float. We also propose two kinds of special individual in the initial population in order to enhance the searching ability of GA. Moreover, we carried out some computational experiments to verify the effectiveness of the proposed method. In future plan, we should develop a more rigid method for nesting so that the proposed approach is amenable to real world applications.

\section{References}

[1] T. Sakaguchi, T. Murakami, S. Fujita and Y. Shimizu: A scheduling method with considering nesting for sheet metal processing; Proc. of the ASME/ISCIE 2012 International Symposium on Flexible Automation, ISFA2012-7197(CD-ROM) (2012)

[2] A. Lodi, S. Martello and M. Monaci : Twodimensional packing problems, A survey; European Journal of Operational Research, Vol. 141, pp. 241$252(2002)$

[3] A. Lodi, S. Martello and D. Vigo:Heuristic and metaheuristic approaches for a class of two-dimensional bin packing problems ; INFORMS Journal on Computing, Vol. 11, pp. 345-347 (1999)

[4] E. G. Coffman Jr, M. R. Garey, D. S. Johnson and R. E. Tarjan: Performance bounds for level-oriented two-dimensional packing algorithms; SIAM Journal on Computing, Vol. 9, pp. 801-826 (1980)

[5] E. K. Burke, G. Kendall and G. A. Whitwell: New placement heuristic for the orthogonal stock-cutting problem; Operations Research, Vol. 52, pp. 655-671 (2004)

[6] G. Chryssolouris, N. Papakostas and D. Mourtzis: A decision-making approach for nesting scheduling: a textile case; International Journal of Production Research, Vol. 38, No. 17, pp. 4555-4564 (2000)

[7] B. S. Baker, E. G. Coffman Jr and R. L. Rivest: Orthogonal packing in two dimensions; SIAM Journal on Computing, Vol. 9, pp. 846-855 (1980) 
[8] E. Hopper and B. C. H. Truton: A review of the application of meta-heuristic algorithms to $2 \mathrm{D}$ strip packing problems; Artificial Intelligence Review, Vol. 16, pp. 257-300 (2001)

[9] D. E. Goldberg and R. Lingle Jr: Alleles, Loci, and the traveling salesman problem; Proc. of the first International Conference on Genetic Algorithms and Their Applications, pp. 160-188 (1985)

[10] Y. Shimizu, T. Sakaguchi and T. Pralomkarn: Multiobjective analysis applied to mixed-model assembly line sequencing problem through elite induced evolutionary method; Journal of Advanced Mechanical Design, Systems, and Manufacturing, Vol. 6, No. 5, pp. 647-660 (2012)

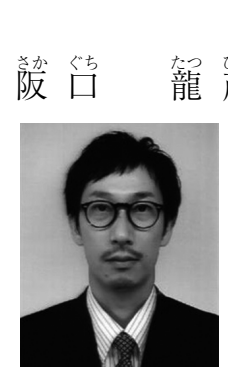

\section{Authors}

\section{(正会員)}

1976 年 4 月 29 日生. 2004 年 12 月大阪 府立大学大学院工学研究科機械系専攻博 士後期課程修了。 2005 年 1 月神戸大学大 学院自然科学研究科助手, 2009 年 4 月豊 橋技術科学大学工学部助教となり現在に 至る。生産スケジューリングやサプライ チェーンマネジメントなどの研究に従事. 日本機械学会, 精 密工学会の会員.
势捄䔝隼人

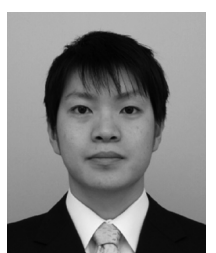

1990 年 4 月 14 日生. 2013 年 3 月豊橋 技術科学大学工学部生産システム工学系 卒業, 2013 月 4 月同大学院工学研究科機 械工学系博士前期課程へ入学し現在に至 る. 精密板金加工のためのネスティング • スケジューリングの研究に従事.

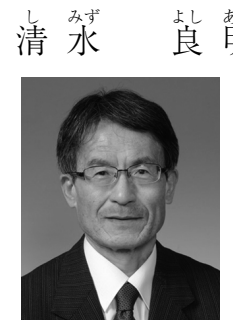

(正会員)

1949 年 3 月 17 日生. 1971 年京都大学 工学部化学工学科卒業, 1976 年同大学院 工学研究科博士課程単位修得退学. 同年 4 月京都大学原子炉実験所助手, 助教授を 経て，1997 年豊橋技術科学大学工学部教 授，2014 年同大学定年退職後, 同大学客 員および名誉教授となり現在に至る. プロセスシステム工学 から展開した最適化工学を標榜しこの普及・研究に腐心. 工 学博士. 本学会論文賞, 日本機械学会生産システム部門学術 業績賞などを受賞. 進化計算学会, スケジューリング学会な どの会員. 